\title{
THE IMPACT OF THE EU CLIMATE POLICY ON THE EU-27 LABOUR MARKETS
}

\author{
Janusz Rosiek \\ Cracow University of Economics, Poland, rosiekj@uek.krakow.pl \\ crossref http://dx.doi.org/10.5755/j01.em.17.3.2114
}

\begin{abstract}
Problems of functioning and proecological development of labour markets have a principal significance for the EU-27 countries, which tend to realize concept of the sustainable development's based economy. It is connected mainly with implementation of the "Europe 2020 Strategy" (http://ec.europa.eu/europe2020/index_en.htm) adopted by the EU. The main goal of this policy is to implement the idea of low-carbon economy through the climate adaptation and mitigation activities. The issue of job creation in the context of greening employment is a Europe-wide question. While employment is not the primary objective of policies to counter climate change, the employment situation in the EU requires the public intervention to redirect policy approach from conventional energy sources and conservation, towards greater efficiency in energy usage and application of the renewable sector outputs.

Keywords: labour markets, green jobs, level and structure of employment, EU-27, climate policy.

JEL classification: E24, J01, J08, J21, J24.
\end{abstract}

\section{Introduction}

The main goal of this article is to present definition, determinants and main tasks of the green growth and employment concept in connection with the EU climate policy. Chapter 2 includes definitions of green jobs and presents their impact on green development of the EU countries in the context of the EU climate policy. In chapter 3 the labour market influence on adapting to environmental change was described taking into account different possible scenarios of various climate policies effects and some mechanisms behind these outcomes. In chapter 4 the scope, instruments and recommendations for green policies affecting labour markets versus challenges and opportunities for green employment and growth were analysed. The most important determinants, mechanisms and indicators of green growth and employment were presented and investigated in chapter 5. Chapter 6 covers concluding remarks.

\section{Defining green jobs and their importance for the green development of EU countries in the context of the EU climate policy: theorethical approach}

Green jobs are one of the key elements of green growth strategy. Green growth means tools by which the current economy can make the transition to a sustainable economy. It involves promoting growth and development while reducing pollution and greenhouse gas emissions, minimizing waste and inefficient use of natural resources, maintaining biodiversity, and strengthening energy security. It requires further "decoupling" of environmental impacts from economic growth, and greening of consumption and production patters, while reducing poverty and improving health and job prospects. Green growth means making investment in the environment a new source of economic growth (OECD, 2010).

The United Nations Environmental Programme (UNEP) defines green jobs as "work in agricultural, manufacturing, research and development $(R \& D)$, administrative, and service activities that contribute substantially to preserving or restoring environmental quality. Specifically, but not exclusively, this includes jobs that help to protect ecosystems and biodiversity; reduce energy, materials, and water consumption through high-efficiency strategies; de-carbonize the economy; and minimize or altogether avoid generation of all forms of waste and pollution." (UNEP, 2008).

According to the International Labour Organization (ILO), "green jobs does not lend itself to a tight definition but certainly includes the direct employment which reduces environmental impact ultimately to levels that are sustainable. This includes jobs that help to reduce the consumption of energy and raw materials, decarbonizes the economy, protect and restore ecosystems and biodiversity and minimize the production of waste and pollution. [...] A somewhat wider concept of "green jobs" might embrace any new job in a sector which has a lower than average environmental footprint, contributes to improving overall performance, albeit perhaps only marginally." (ILO, 2008). 
In the opinion of the European Commission (EC) to direct employment effects in green industries, greening the economy can have indirect effects in other areas, such as substituting environmentally inefficient jobs, contributing to the greening of existing jobs, and eliminate existing jobs as well as establishing new jobs. In addition, indirect knock- on effects may ripple through the economy and affect other parts of the labour market via price, wage and income effects. (EC, 2009).

Green jobs reduce the environmental negative impact of enterprises and economic sectors, ultimately to levels that are sustainable. Green jobs are found in many sectors of the economy from energy supply to recycling and from agriculture and construction to transportation. They help to cut the consumption of energy, raw materials and water through high-efficiency strategies, to de-carbonize the economy and reduce greenhouse gas emissions, to minimize or avoid altogether all forms of waste and pollution, to protect and restore ecosystems and biodiversity (UNEP, 2008, p. 5).

\section{The labour market impact of adapting to environmental change}

Employment levels and structures will not only be affected by polices aiming at environmental sustainability, but also by the need to adapt to climate and other environmental changes that are already happening now. These may become worse in the future, depending on the degree and success of mitigation strategies. On the one hand, climate and other environmental change destroy certain production factors (e.g. farm lands, touristic resorts, and fish stocks) and disrupt production processes (e.g. through hurricanes and flooding) which leads to the reallocation of labour and capital across and within sectors and regions. On the other hand, climate change can create new job opportunities as new markets emerge in specific sectors or regions and investments are made to cope with the changing environment. It should be borne in mind though that the capacity for effective adaptation is limited and is likely to entail, from a certain point onwards, very high social, environmental and economic costs (EMCO, 2010, p. 6).

Studying the complex set of direct and indirect effects of job creation and destruction requires the use of economic models in which scenarios of none environmental policy intervention are compared to those which do involve environmental policies. In principle, the more direct effects of climate policies could be monitored in a rather straightforward way through statistical indicators on employment in specific green activities. In practice however, there are severe limitations in the availability of comparable and good quality data even for specific green sectors. These data could include, for example:

- employment in energy intensive production sectors and energy production based on fossil fuels (negative direct effect),

- employment in renewable energy sectors (positive direct effect),

- employment in manufacturing of clean technology components (positive direct effect)

In addition to instances of direct job creation or destruction, there are indirect employment effects that need to be taken into account. They are however much more difficult to estimate and depend on the type of green policies and instruments applied, and on the ability of labour markets and their institutions to cope with and facilitate structural change (EMCO, 2010, p. 6). Table 1 illustrates different possible scenarios of various climate policies and some mechanisms behind these outcomes:

- scenario A describes "net loss of jobs" outcome with a high loss of jobs in "dirty" industries which is not matched by the creation of new jobs in green activities,

- scenario B "green jobs but lower productivity": implies moderate carbon leakage but higher energy price and lower real income, probably lower productivity - depends on whether positive effects dominate negative indirect effects or not,

- scenario $C$ implies "loss of dirty jobs" compensated by higher productivity (in green or other sectors),

- scenario D would be the "green growth" scenario (EMCO, 2010, p. 7). 
Table 1. Direct and indirect employment effects of climate policies - different scenarios

\begin{tabular}{|c|c|c|}
\hline $\begin{array}{c}\text { Various } \\
\text { outcomes of } \\
\text { climate policies }\end{array}$ & Mainly negative direct effects & Mainly positive direct effects \\
\hline $\begin{array}{l}\text { Mainly negative } \\
\text { indirect effects }\end{array}$ & $\begin{array}{l}\text { A. "Loss of jobs" } \\
\text { - green energy with higher energy cost } \\
\text { - higher price on carbon (fossil fuels) } \\
\text { - carbon leakage } \\
\text {-strong decline of traditional "dirty" } \\
\text { production } \\
\text { - not enough new low carbon or green } \\
\text { activities } \\
\text { - lower GDP and real income; negative } \\
\text { feedback effects }\end{array}$ & $\begin{array}{l}\text { B. "Green jobs but lower productivity" } \\
\text { - no significant carbon leakage }{ }^{1} \\
\text { - direct job losses moderate } \\
\text { - increase of renewable energy } \\
\text { - increase of low carbon jobs } \\
\text { - lower real income and negative indirect effects } \\
\text { - lower productivity } \\
\text { - the overall effect on employment is sum of mainly } \\
\text { positive direct effects and negative indirect effects }\end{array}$ \\
\hline $\begin{array}{l}\text { Mainly positive } \\
\text { indirect effects }\end{array}$ & $\begin{array}{l}\text { C. "Loss of "dirty" jobs } \\
\text { - direct job losses ("dirty" production) } \\
\text { - carbon leakage } \\
\text { - some but not high enough increase of } \\
\text { renewable energy and low carbon jobs } \\
\text { - positive indirect effects through higher } \\
\text { productivity which compensates the } \\
\text { negative real income effect of higher } \\
\text { energy costs }\end{array}$ & $\begin{array}{l}\text { D. "Green growth" } \\
\text { - new efficient green or low emission energy } \\
\text { production } \\
\text { - no significant carbon leakage } \\
\text { - new productive activities in industry sector (energy } \\
\text { efficient technology, greener production in traditional } \\
\text { sectors), fully compensating the loss of jobs in "dirty" } \\
\text { production } \\
\text { - increased or not at least decreased productivity } \\
\text { - no negative effect on GDP, real income and long-run } \\
\text { employment }\end{array}$ \\
\hline
\end{tabular}

Source: EMCO, 2010, p. 7

\section{The scope, instruments and recommendations for green policies affecting labour markets vs. challenges and opportunities for green employment and growth}

OECD's Green Growth Strategy (Miranda G. et al. (2011), p. 77-78) identify several functions that government can pursue to enable green growth. In its deliberations during the study visit, the team of experts found several areas within these tenets that it believed government policy and practice were insufficient in enabling green growth in countries and regions. In broad terms, these areas include:

- lack of a clear definition of the green economy and green jobs,

- insufficient public awareness of green jobs as a driver of future growth,

- need for greater leadership on the part of government to champion green growth,

- confusing administration of some policies stemming from poor coordination among levels of government (including the European Union),

- unsuccessful attempts at forming meaningful public/private partnerships,

- missed opportunities to provide funding to green business start-ups and incentives to green industries to develop more fully.

- weak institutional capacities at regional and local levels to understand, endorse, define and deliver green growth policies and programmes.

By identifying these areas, one can state that the government has failed to address these issues. The government could do more in these areas, based upon the interviews and the experts' knowledge of practices and initiatives undertaken by governments in other parts of the world. (Miranda G. et al., 2011, p. 78).

Employment policies will have to address these much broader impacts of greening the economy and take into account the interdependence between the economic, ecological, and even social dimension of the issue. For policy purposes, it is useful to avoid activity-based definitions of green jobs which would run the risk of focusing on a too narrow area of the economy. Instead, it proposes to take a broad policy-based approach that acknowledges the complex inter-linkages between climate change and environmental sustainability on the one hand, and labour markets on the other hand. There are two broad groups of policy instruments for addressing the environmental challenges: pricing and non-pricing instruments. Both can have

\footnotetext{
${ }^{1}$ carbon leakage occurs when there is an increase in carbon dioxide emissions in one country as a result of an emissions reduction by a second country with a strict climate policy.
} 
a significant effect on employment. In addition, the regional and sectoral distribution of labour will also be affected directly by climate and environmental changes. Economic or market-based instruments (including pricing instruments) essentially aim at imposing a price on environmentally harmful aspects of production and consumption, thus providing incentives to producers for internalizing the external costs of environmentally harmful behaviour. Economic instruments include (EMCO 2010, pp. 4-5):

- taxing environmentally harmful activities or production factors,

- charges and tradable permits (e.g. emissions trading schemes),

- subsidies promoting environmentally friendly production (while phasing out subsidies for

- environmentally harmful inputs and products).

Non-pricing instruments try to influence the behaviour of economic consumers, companies and individuals by other means than price signals. They include for example:

- regulatory measures (e.g. technical standards on car emissions, industrial pollution, product ingredients etc., eco-design i.e. introduction and monitoring of minimum energy-efficiency standards: eco-labelling, i.e. labelling of products and services),

- awareness raising and promoting the consumption of green products,

- research and technology development for more environmental use of resources,

- stimulation of transfer of knowledge and information,

- fostering voluntary environmental agreements between industries,

- completion of the internal market in the EU,

- green public procurement.

The OECD Strategy provides a set of principles, tools, and recommendations that are intended "to assist governments to identify the policies that can help achieve the most efficient shift to greener growth" (OECD, 2010, p. 9). The strategy provides a framework to help "ensure that green growth policies contribute to greater economic integration, technology co-operation and reduced pressure on scarce environmental resources" (OECD, 2010, p. 9). An important component of the strategy is the role of government policy in an effective transition toward greener growth, with an emphasis on the importance of co-ordination among government units and the need for meaningful partnerships between government, the private sector, and educational institutions.

Strategies and practices to enable green growth, according to the OECD Growth Strategy, require a mix of policy instruments, including market-based approaches, regulations and standards, measures to incentivize R\&D, and information-based instruments to facilitate consumer choices. The OECD Green Growth Strategy recognizes that green growth initiatives need to be embedded in a coherent, integrated strategy covering demand and supply aspects, both economy-wide and at the regional and sectoral levels (Miranda et al., 2011, p. 74).

The government sector has a key role in enabling green growth. It must pursue policies that provide proper incentives to develop green technologies and form green businesses, ensure that market pricing signals are not distorted by misdirected government policy, and make available sufficient resources to shift the economy from its current trajectory of intensive carbon dependency to one that is much more dependent on greener technologies and consumption practices (Miranda et al., 2011, p. 74). The detailed recommendations for economic policy could be the following (Miranda et al., 2011, pp. 90-94):

- setting definitions and objectives to better support the green economy,

- building capacities on the green economy,

- improving the coordination of policies and programmes,

- effectively supporting the development of green markets,

- supporting green entrepreneurship.

\section{The most important determinants and indicators of green growth in EU countries}

A natural starting point for defining green growth indicators is the sphere of production where economic inputs are transformed into economic outputs (goods and services) (Figure 1). The most important indicators are connected mainly with:

- environmental and resource productivity, representing the volume of output per unit of services from natural assets,

- greenhouse gas emissions (GHG) emissions per unit of GDP or per employee,

- the share of total environmental tax revenues in total revenues from taxes. 


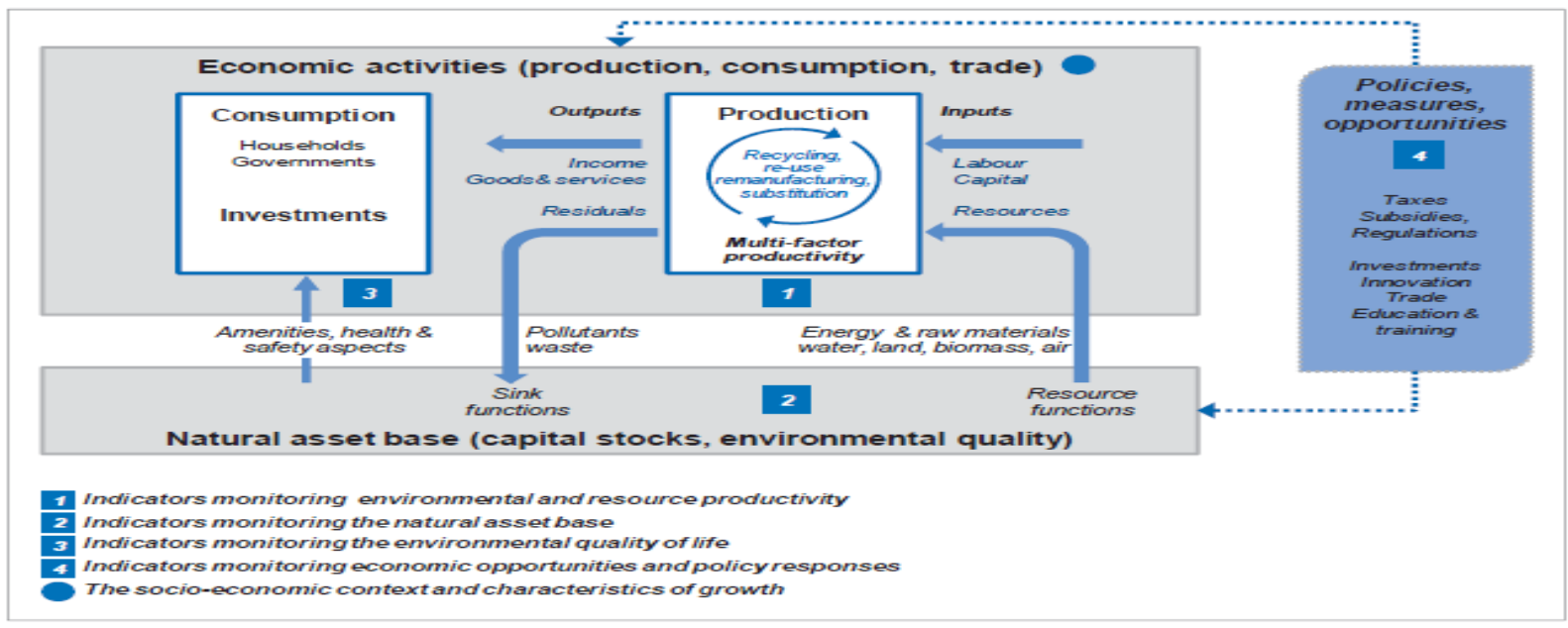

Figure 1. Framework for green growth indicators Source: OECD, 2011b, p. 115

As shown in Figure 2 for the case of $\mathrm{CO} 2$ emissions, the growth rates of GDP and other measures of output tend to outstrip the growth rates of environmental inputs into the production system or the need for sink services provided by the environment to human less environmentally harmful economic growth. activity. Rising environmental productivity is a necessary but not sufficient condition for pursuing less environmentally harmful economic growth. For this, rising productivity should be accompanied by absolute declines in environmental services in those areas where there is unsustainable use of environmental assets. A second message that arises here is that although such absolute "decoupling" has occurred in some countries and in some areas, it is less prevalent than relative decoupling. Cases of absolute decoupling in OECD countries are, for example, found for emissions of acidifying substances and related trans-boundary air pollution (OECD, 2011b, p. 117).

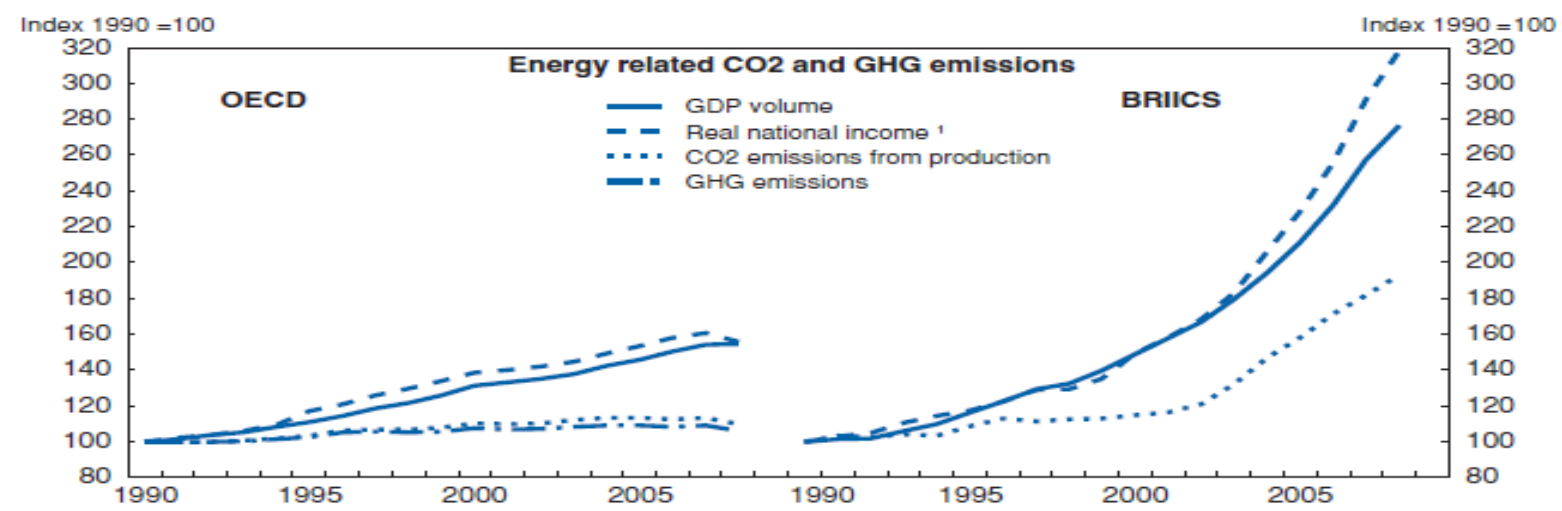

1. Real net national income for OECD, and real gross national income for BRIICS.

Figure 2. Decoupling trends - CO2 and GHG emissions (Index 1990=100) Source: OECD, 2011b, p. 118

Figure 3 illustrates the share of employment in the three core sectors of interest for a selection of European countries and the United States in 2002 and in 2007, as well as the average annual growth rate between these two points in time. The evolution of employment differs significantly among countries.

Nordic countries (Finland, Sweden), Spain and Italy stand out, while some large economies such as the United States or Germany appear stable. In Central Europe, Hungary, Czech Republic, Slovenia the data reveal a quite high share of employment in purely green sectors (OECD, 2011a, p. 30). 


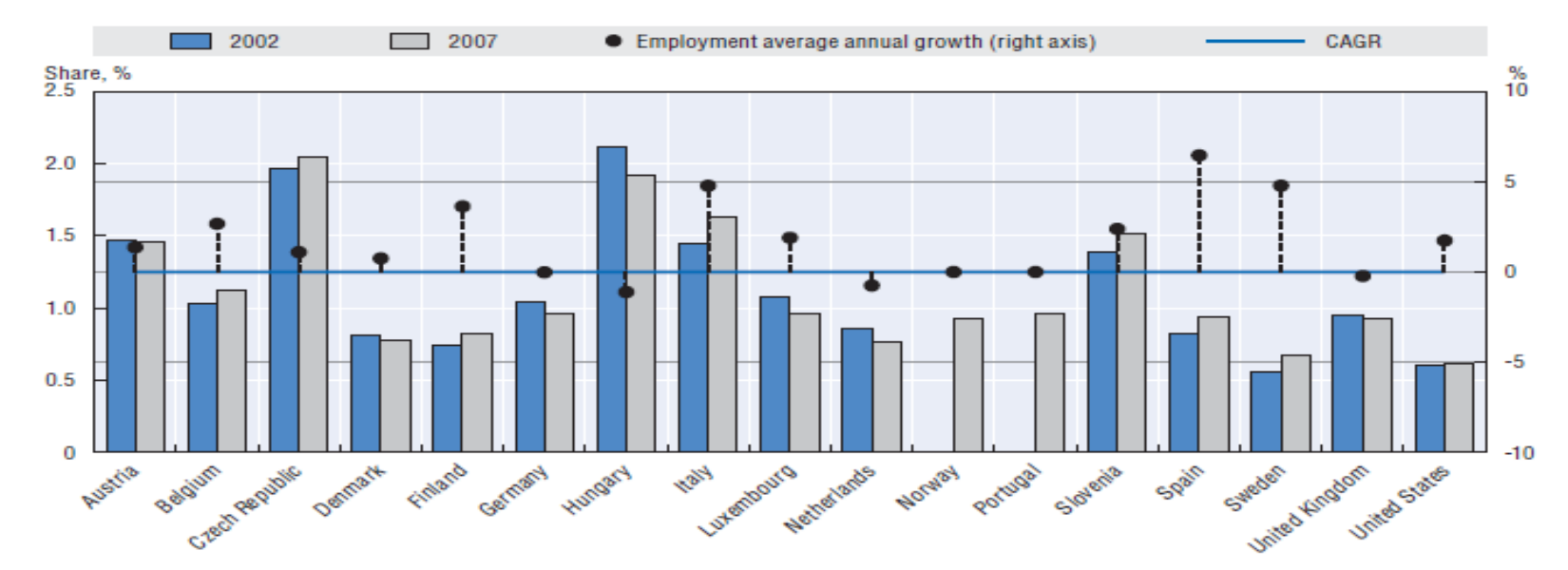

- Total economy corresponds to ISIC Sectors 10 to 74, excluding Sectors 65 to 67. ISIC 37: Recycling.

ISIC 41: Collection, purification and distribution of water.

ISIC 90: Sewage and refuse disposal, sanitation and similar activities.

Note: Employment figures in STAN are sourced from national accounts and may include adjustments for informal non-registered firms.

Figure 3. Share of employment in ISIC sectors 37,41 and 90 in percentage of total economy, years: 2002 and 2007

Source: OECD Structural and Business Statistics (SDBS) Database, and STAN Database for ISIC Sector 90

Figure 4 illustrates the total volume of greenhouse gas emissions (GHG) as a share of gross domestic product (GDP) and the scale of this indicator's changes in years: 2000, 2004, 2007 and 2009. The EU New Member States (especially: Bulgaria, Romania, Estonia, Poland and Slovakia) were definite leaders taking into account relatively high emissions' levels and the range of their reductions. This indicates the effectiveness of the EU climate policy, but its goals must be considered in much broader context.

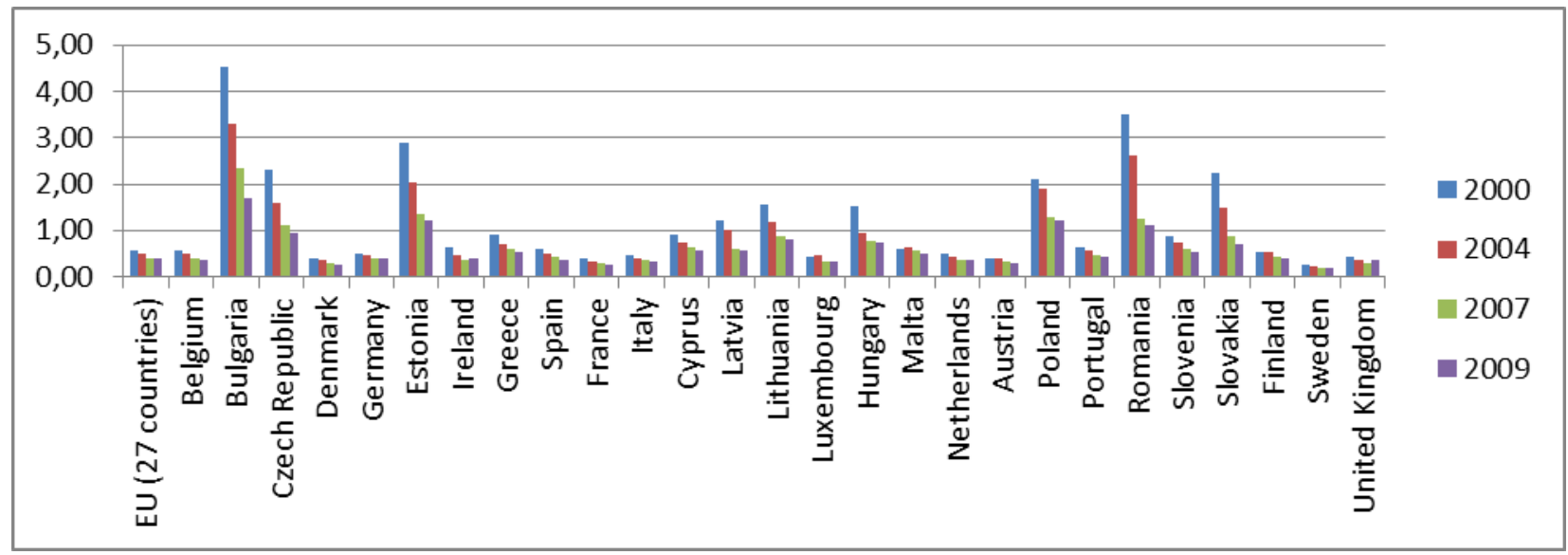

Figure 4. Total greenhouse gas emissions (GHG) as a share of gross domestic product (GDP) (in \%), years: 2000, 2004, 2007, 2009

Source: own compilation based on Eurostat data

Figure 5 shows changes of GHG/GDP ratio in the same years. The scale of emissions per employee also decreased in the EU-27 and in almost all Member States (beside Lithuania, which increased its emissions per employee (except 2009) and Latvia which emissions stayed almost at the same level in analysed years). Although in two initial years of analysed period (2000 and 2004) this indicator was relatively high in many countries and also at the EU level. This shows a growing determination concerning implementation of the EU climate policy at least referring to the reduction of GHG emissions since 2007. 


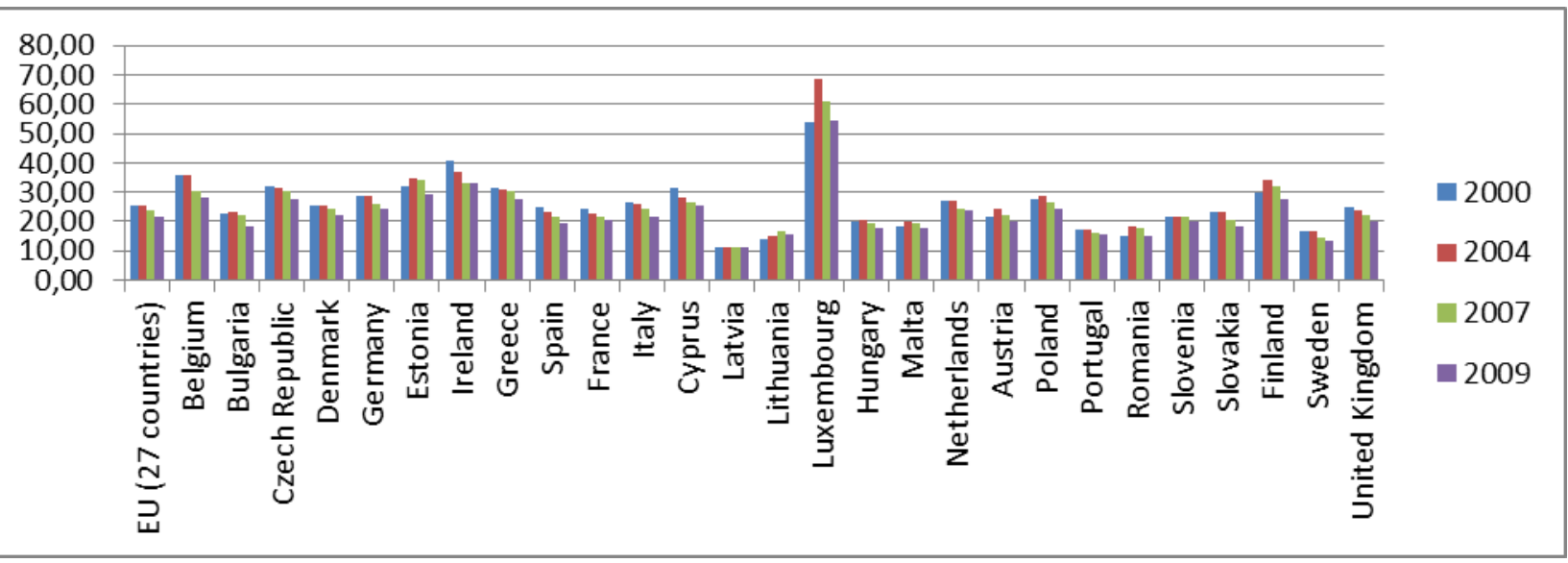

Figure 5. Total greenhouse gas emissions (GHG) as a share of employment (age: 15-64) (in \%), years: 2000, 2004, 2007, 2009

Source: own compilation based on Eurostat data

\section{Conclusions}

Green jobs are among key elements of green growth strategy. Green growth means the instruments by which the current economy can make the transition to the sustainable economy. It involves promoting growth and development by reducing pollution and greenhouse gas emissions, minimizing waste and inefficient use of natural resources, maintaining biodiversity, and strengthening energy security. The evolution of green employment differs significantly between EU and OECD countries. It is revealed mainly by differentiated value of indicators characterizing GHG emissions and employment in the key areas of green growth. The government plays a key role in encouraging green growth. It must pursue policies that provide proper incentives to develop green technologies and form green businesses, ensure that market pricing signals are not distorted by misdirected government policy, and make available sufficient resources.

\section{References}

1. EMCO (2010). Towards a greener labour market - The employment dimension of tackling environmental challenges. EMCO Reports, Final report endorsed by EMCO, Issue 4, November, ec.europa.eu/social/BlobServlet?docId=6438

2. EC (2009). Communication: GDP and beyond: Measuring progress in a changing world, (COM (2009) 433 final), http://ec.europa.eu/index_en.html.

3. ILO (2008). Global Challenges for Sustainable Development: Strategies for Green Jobs, ILO Background Note G8 Labour and Employment Ministers Conference, Niigata, Japan, http://www.ilo.org/public/english/bureau/dgo/speeches/somavia/2008/g8paper.pdf.

4. Miranda G. et al. (2011). Climate Change, Employment and Local Development in Poland, OECD Local Economic and Employment Development (LEED) Working Papers, 2011/22, OECD 2011, http://dx.doi.org/10.1787/5kg0nvfvwjd0-en.

5. OECD (2010). Interim Report of the Green Growth Strategy: Implementing our commitment for a sustainable future Meeting of the OECD Council at Ministerial Level, 27-28 May.

6. OECD (2011a). Entrepreneurship at a Glance 2011, OECD Publishing, http://dx.doi.org/10.1787/9789264097711 en

7. OECD (2011b). Towards green growth, http://www.uncsd2012.org/rio20/content/documents/towards\%20green\%20growth\%20full\%20report.pdf.

8. UNEP, ILO, IOE, ITUC (2008). Green jobs: Towards decent work in a sustainable low-carbon world, Nairobi, http://www.unep.org/labour_environment/PDFs/Greenjobs/UNEP-Green-Jobs-Report.pdf.

9. http://ec.europa.eu/europe2020/index_en.htm. 